\title{
MONASCUS PIGMENT PRODUCTION WITH FOOD RESIDUES (STALE BREAD AND SOUR YOGHURT): A COMPARATIVE KINETIC ANALYSIS
}

\author{
(BAYAT EKMEK VE EKŞİ YOĞURT GIBI GIDA ATIKLARINDAN \\ MONASCUS PIGMENTI ÜRETIMI: KIYASLAMALI KINETIK \\ ANALIZLERI)
}

\author{
Evren ALTIOK ${ }^{1}$, Duygu ALTIOK ${ }^{2}$,Gülşen NAS ${ }^{3}$
}

\begin{abstract}
Colorants are one of the most important additives in food industry. Preference of natural colorants has become highly concerned compounds since many studies have indicated the harmful effect of synthetic colorants. The aim of this study was to investigate and compare the pigment production yield of Monascus purpureus from different food residues. Growth parameters of M.purpureus were followed during 14 days for the responses of yield, pigment profile and Monascus metabolites. Results indicated that dairy residues and stale bread could be economic, efficient and easily available substrate for M.purpureus pigment production.
\end{abstract}

Keywords: Monascus pigments, Food residues, Kinetic analysis, Natural food colorants

\section{$\ddot{O} Z$}

Gıda endüstrisinin en önemli katkı bileşenlerinden bir tanesi renklendiricilerdir. Sentetik renklendiricilerin zararlı etkileri ile gıdalarda doğal olan renklendiriciler tercih edilmektedir. Bu çalışmanın amacı, Monascus purpures'un ürünü olan pigmentinin çeşitli gıda atıklarının kullanılarak üretiminin incelenmesi ve klyaslanmasıdır. Verim, pigment profili ve Monascus metabolitleri açısından M.purpureus' un üreme parametreleri tanıml ve kompleks ortamlarda 14 gün boyunca izlenmiştir. Elde edilen bulgular, gıda atıklarından süt ürünlerinin ve bayat ekmeklerin M.purpureus ile pigment üretimi için ekonomik bir substrat olabileceğini göstermiştir.

Anahtar Kelimeler: Monascus pigmenti, Gıda atıklarl, Kinetik analiz, Doğal gıda renklendiricileri

\footnotetext{
${ }^{1}$ Giresun Üniversitesi, Mühendislik Fakültesi, Genetik ve Biyomühendislik Bölümü, GíRESUN, evren.altiok@giresun.edu.tr (Corresponding Author)

${ }^{2}$ Giresun Üniversitesi, Mühendislik Fakültesi, Gıda Mühendisliği Bölümü, GíRESUN, duygu.altiok@giresun.edu.tr

${ }^{3}$ İstanbul Aydın Üniversitesi, Mühendislik Fakültesi, Gıda Mühendisliği Bölümü, İSTANBUL, gulsennas@aydin.edu.tr
} 


\section{INTRODUCTION}

Many natural and synthetic colorants are used in food, textile, pharmaceutical and cosmetic industry. Since many studies indicated the serious health risks of synthetic colorants, replacing the synthetic colorants with natural colorants gained high concern and importance. As parallel to this, consumers are much more conscious and sensitive, and thus showing resistance to use synthetic ones because of their possible health threatening effects, like allergy, hyperactive behaviors and poor attention in a group of children [1-2]. The potential danger of some synthetic colorants such as indigocarmine, tartrazine, sunset yellow and allura red have been documented [3-6]. These results have stimulated the replacement of synthetic colorants by natural ones.

In recent years, there is a growing interest to obtain the biologically active compounds from natural sources. Pigments can be derived from plants, animals and microorganisms. Among them Monascus purpureus has been standing out due to its valuable bio-components and pigment production ability. Monascus is a filamentous fungus belonging to the genus Monascus, family monascaceae and class ascomyceta. It has the power to synthesising secondary metabolites as the bio-pigments with connected polyketide structure. Monascus $s p$ produces six primary pigments, the colours of which are yellow (ankaflavin, monascine), orange (rubropunctatin, monascorubrine) and red (rubropuntantamine, monascorubramine) [7]. The major bioactive compounds of Monascus sp. have not only good coloring ability but also exhibit important additional bioactivities due to their antioxidative [8], cholesterol lowering [9], antimicrobial, antiproliferative and cytotoxic properties [10-13]. Thus, the implementation of Monascus pigment as a coloring agent in food products provides also an additional advantage of specific activities.

The pigment production efficiency of Monascus purpureus depends on substrate type and some environmental factors during the fermentation process. Chemically defined media has many advantages over the complex media, in which the effect of each component can be well understood. However, it is comparatively higher cost process. Thus, alternatively, easily available and valuable food components in food residues, agro industrial byproducts and wastes can be processed as a substrate to yield economic fermentation and value added high pigment output. So far many agro industrial residues and crop such as coconut oil cake, corn/corn cob, rice/rice bran, jack fruit seed, groundnut oil cake, and wheat bran were used as substrate for Monascus pigment production [14-15]. Monascus purpureus produces different secondary metabolites with varying bioactivities by different substrates [16]. Past research on Monascus purpureus has concentrated only two broad issues; pigmented rice production and their metabolites' bioactivities. Considering the issue of apprising food residues as substrates in fermentation media to produce value added products, the literature has almost limited details of kinetic explanation of the microorganism adaptation and their metabolic activities regarding the Monascus pigments production.

Against this background, the aim of this study was to investigate and compare the pigment production yield of Monascus sp. on different food residues. For this purpose, YGC and LMYGC were used as a defined media to investigate the Monascus metabolites. Since stale bread and sour yoghurt are easily available and large amount of food residue, they were appraised as a potential substrate of M.purpureus. To our knowledge, in the literature there were no studies about the evaluation of stale bread and sour yoghurt for the production of Monascus pigments (MPs). Comparative kinetic studies were performed for the feasibility of the process, in terms 
of the growth yield, product formation and type of Monascus metabolites.

\section{MATERIALS AND METHODS}

\subsection{Microorganism and Growth Medium}

M. purpureus was obtained from Refik Saydam National Type culture Collection (RSSK) in Turkey. Stocks of culture in freeze-dried ampoules were activated in YM broth at $30{ }^{\circ} \mathrm{C}$ for 2 days and then transferred to Patato Dextrose Agar (PDA, oxoid) and further 7 days incubation. M. purpureus spores were collected with a $5 \mathrm{~mL}$ of FTS and diluted to obtain $10^{6}$ spores $/ \mathrm{mL}$. They were seeded consecutively on to the PDA and incubated for 7 days in order to keep ready for further studies.

YGC (Sigma- Aldrich) and litmus milk fortified YGC agar (LM-YGC agar) were used as defined medium. Chloramphenicol in YGC formulation inhibits the accompanying bacterial flora, but allows the growth of $M$. purpureus. In order to determine the effect of milk products on the growth of $M$. purpureus, litmus milk was added (15\%) to the YGC formulation. $2 \mathrm{~mL}$ of Monascus spores were sprayed onto the agar surface to achieve $10^{12}$ spores/petri surface.

\subsection{Preparation of Food Residues}

Food residues (moisturized stale-bread and sour-yogurt) were used as substrates to compare the pigment yield. Stale-bread was obtained from local market, which was collected in waste bin. Bread was cut into cubes of approximately $1 \mathrm{~cm}^{3}$ in size and autoclaved for 15 min at $121{ }^{\circ} \mathrm{C}$. Cubes were grounded to $2 \mathrm{~mm}$ particle size using a sterile blender. Moisture of bread was measured by infrared moisture balance (AND, MX-50) at $105{ }^{\circ} \mathrm{C}$. Sterilized distilled water was poured onto the bread particles to achieve $60 \%(\mathrm{w} / \mathrm{w})$ humidity.

Aseptically, $15 \pm 0.2$ grams of moisturized stale bread granules were transferred into each petri dish, and then $2 \mathrm{~mL}$ of Monascus spores were sprayed homogeneously onto the granules. Sour yoghurt was collected from a local market in Istanbul, whose expire date was passed out. $\mathrm{pH}$ and the amount of total solids of sour yoghurt were measured. $15 \mathrm{~mL}$ of sour yoghurt was poured into each petri dish and $2 \mathrm{~mL}$ of Monascus spores were inoculated onto sour yoghurt.

\subsection{Determination of Biomass}

The biomass during the growth kinetic studies in each substrate used was directly determined by simple treatment performed by Zhang et al., 2015 [17] with a slight modification. Whole petri dish was used to determine the mycelia grown over the surface. 3 times $\times 3 \mathrm{~mL}$ of distilled water was used to collect the mycelia subsequently. They were recovered by filtering the solution immediately through eight layers of gauze. The filter residue was washed three times with distilled water. Then the yield of biomass was determined gravimetrically after drying at $70^{\circ} \mathrm{C}$ overnight to a constant weight.

\subsection{Extraction of Monascus Pigments}

Monascus spores were collected every day from incubated petri dishes by washing a surface with $2 \mathrm{~mL}$ of ethyl alcohol. MPs included solution was then collected carefully by pipetting over the petri dishes. 5 times subsequent washing was performed and samples were brought together. In each sample, the volume was added up to the $20 \mathrm{~mL}$ with ethyl alcohol for further analysis. Prior to the spectrophotometric measurements, samples were centrifuged at $1000 \mathrm{rpm}$ for 3 minutes (Hettich Rotofix $32 \mathrm{~A}$ ). 


\subsection{Measurement of Monascus Pigments}

Optical density (OD) of harvested pigment solution was measured at $412 \mathrm{~nm}$ and $500 \mathrm{~nm}$ with a UV-visible spectrophotometer (Perkin Elmer), representing yellow and red pigment production (expressed as OD-value per gram of dry solid material_gdsm), respectively, taking account a dilution factor. Growth kinetics and consequently pigment yield were followed during 12 day fermentation.

\subsection{Determination of Ethanol during the Growth Studies}

Petri surface was divided into pieces with a size of $2 \mathrm{~cm}^{2}$. Samples were taken into the test tube including $5 \mathrm{~mL}$ of distilled water to investigate the ethanol content during the fermentation period. Test tubes were homogenized on a vortex and centrifuged at $3000 \mathrm{rpm}$ for 3 minutes. The volume of supernatant was completed to $50 \mathrm{~mL}$ with distilled water. After distillation of the ethanol in the sample into the $\mathrm{K}_{2} \mathrm{Cr}_{2} \mathrm{O}_{7}$ solution, it was analyzed by titrimetric method between $\mathrm{K}_{2} \mathrm{Cr}_{2} \mathrm{O}_{7}$ and $\mathrm{Fe}^{2+}$ according to the Skoog et al., 2003 [18]. Experiments were performed in three replicates and results were presented as the mean values.

\subsection{HPLC Profile of Monascus Metabolites}

HPLC analyses were performed in order to determine Monascus metabolites of Monacolin $\mathrm{K}$ and Lovastatin according to the method developed by Seenivasan et al., 2015 [19] with a slight modification. Agilent 1100 series HPLC equipped with Lichrospher RP C18 column $(4.6 \times 250 \mathrm{~mm}, 5 \mu \mathrm{m})$ was used in the analyses. Detection was carried out by UV detector at $238 \mathrm{~nm}$ for Lovastatin (Monacolin K) and anologues and/or intermediates of lovastatin synthesized during the fermentation. Samples were filtered through $0.45 \mu \mathrm{m}$ membrane filter before injection. The mobile phase was acetonitrile: water ( $\mathrm{pH}$ was adjusted 2.5 with $\mathrm{H}_{3} \mathrm{PO}_{4}$ ) mixture at a ratio of 45:55 (v/v). Flow rate was $1 \mathrm{~mL} / \mathrm{min}$. Gallic acid (Sigma) as an external HPLC standard was used in relative comparison of the Monascus pigments.

\subsection{Modelling of Growth Kinetics}

The Monod equation relates the specific growth rate, $\mu$, and substrate concentration (S), and is given by:

$$
\mu=\frac{\mu_{\max } S}{K_{S}+S}
$$

In order to describe growth kinetics for both exponential and stationary phases, the logistic equation is introduced:

$$
\frac{d X}{d t}=\mu X\left(1-\frac{X}{X_{m}}\right)
$$

where $\mathrm{X}$ is the biomass concentration and $\mathrm{X}_{\mathrm{m}}$ is the stationary phase population size, or upper biomass concentration above which bacteria do not grow. The constant $\mathrm{K}_{\mathrm{s}}$ is the concentration of the rate-limiting substance when the specific rate of growth is equal to one-half of its maximum [20].

MPs including Monacolin K are secondary metabolites of Monascus. Product formation in fermentation is described by Luedeking and Piret kinetics. The product formation rate 
depends upon both the instantaneous biomass concentration $X$ and growth rate $\mathrm{dX} / \mathrm{dt}$ in a linear fashion:

$$
\frac{d P}{d t}=\alpha \frac{d X}{d t}+\beta X
$$

where $\mathrm{P}$ is the product concentration; $\alpha$ and $\beta$ are empirical constants that possibly vary with fermentation conditions. $\alpha$ and $\beta$ also explain the growth-associated and non-growth associated product formation, respectively.

Equations 2 and 3 were integrated as shown by Equations 4 and 5, respectively.

$$
\begin{aligned}
& X=\frac{X_{0} * e^{\mu_{m} t}}{1-X_{0} / X_{m}\left(1-e^{\mu_{m} t}\right)} \\
& P=P+\alpha\left(X+X_{0}\right)+\beta \frac{X_{m}}{\mu_{m}} \ln \left\{1-\frac{X_{0}}{X_{m}}\left[1-e^{\mu_{m} t}\right]\right\}
\end{aligned}
$$

\section{RESULTS AND DISCUSSION}

In this study, M.purpureus was cultivated on different substrates in order to determine the MPs production performance using different food residues. The growth rate, MPs production rate and a change in ethanol concentration during the fermentation were investigated during the study. YGC was selected as a defined media in order to eliminate the other bacterial growth but allowing the M.purpureus growth. An effect of litmus milk on the growth was also searched. The aim was to compare pigment production by different substrates under the same conditions of incubation time and temperature $\left(30^{\circ} \mathrm{C}\right)$.

\subsection{Biomass}

Due to the distinct chemical compositions, i.e. carbon and nitrogen source, elemental richness and even moisture content, between substrates, they provided different environment for the mycelial growth, metabolite production and substrate consumption. Hence, the kinetic parameters of $M$. purpureus were apparently different depending on the substrates used. All of the substrates used in this study served suitable nutrients for the M. purpureus growth (Fig. 1). M.purpureus formed a typical colony with its orange color, whose morphological characteristics were similar with the descriptions given by Rasheva et al., 1998 [21]. 


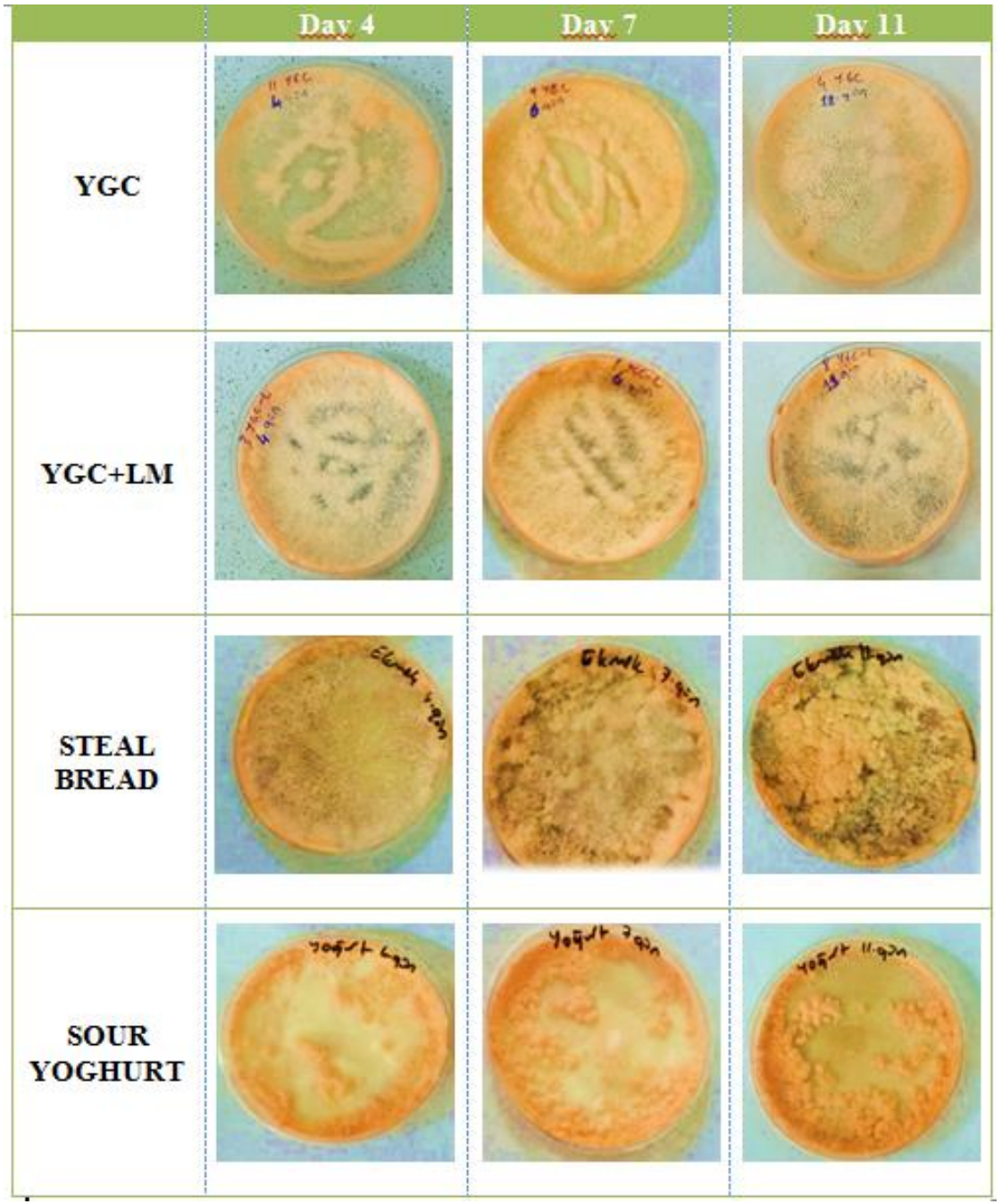

Figure 1. Growth performances of Monascus purpureus. on different substrates within 12 days

\subsection{Growth Kinetics of M. Puppureus}

In these experiment amount of inoculum was adjusted as enough to eliminate the lag phase of the growth curve. Hence, an exponential growth phase, extending from initial period to 168 $\mathrm{h}$ of the incubation time, and a stationary phase were seen thereafter in all of the substrates worked except stale bread (Fig.2). The biomass dry weight continued to increase to a highest value until $240 \mathrm{~h}$ of incubation period when stale bread was used. 


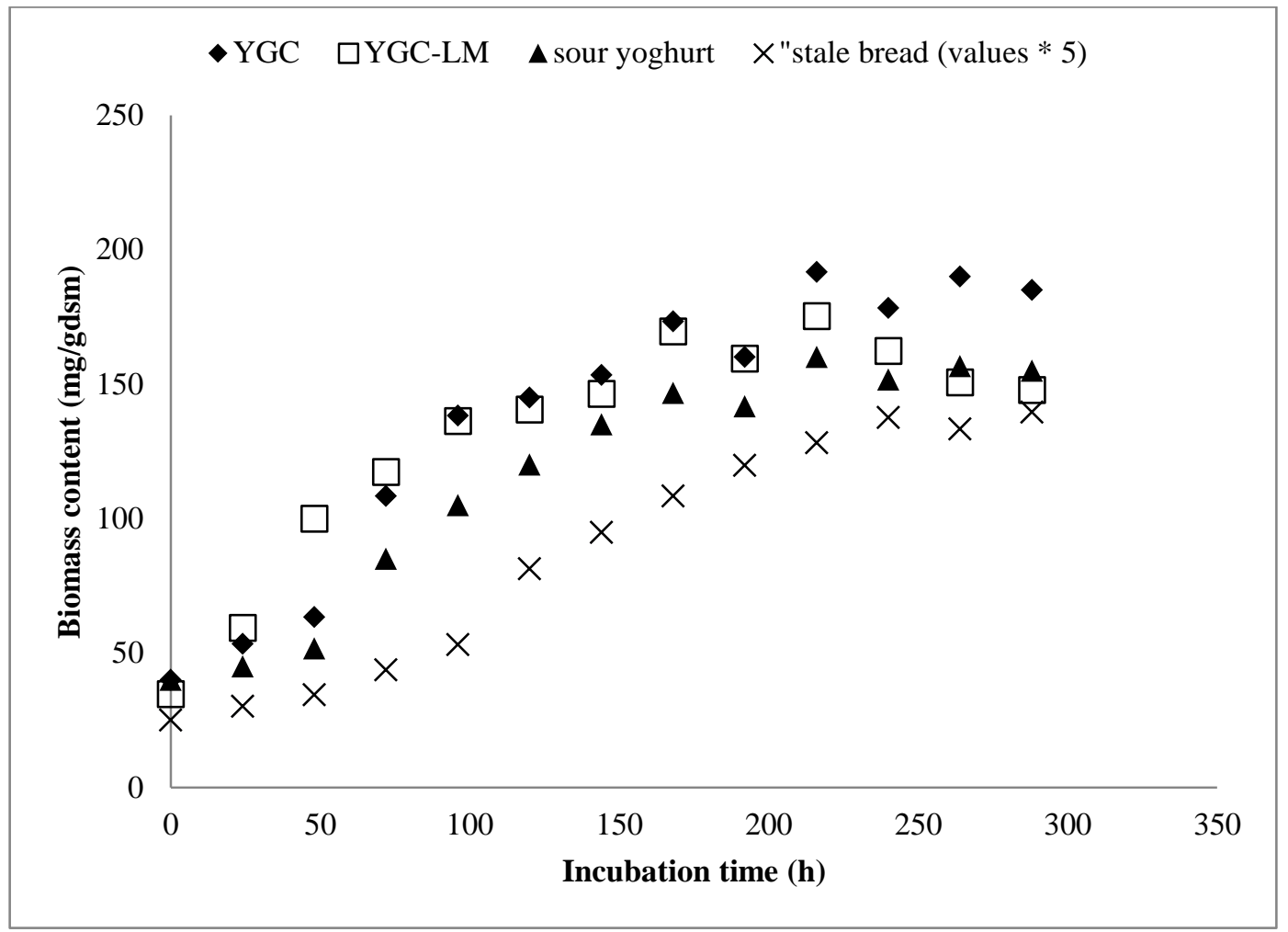

Figure 2. Biomass kinetics of M. purpureus grown on defined media (YGC and YGC-LM) and food residues (stale bread and sour yoghurt) following 12 days (value belongs to stale bread is multiplied with 5 to see the trend apparently)

Within three days rapid biomass formation of M.purpureus was obtained on YGC-LM plate as compared to YGC only. The relative biomass amount with YGC was $190 \mathrm{mg} / \mathrm{gdsm}$, followed $175 \mathrm{mg} / \mathrm{gdsm}$ with YGC-LM at the highest levels as shown in Fig. 2. Litmus milk contains the carbohydrate lactose along with three main proteins, i.e. casein, lactalbumin and lactoglobulin. Tseng et al., 2000 [22] indicated higher protease activity and lower pigment yield in the medium with lactose replacing of glucose. This could increase the metabolic activities of the mycelia, and so the biomass yield was higher when compared with the YGC media. The relative biomass amount was decreased to $160 \mathrm{mg} / \mathrm{gdsm}$ with sour yoghurt, and $27.5 \mathrm{mg} / \mathrm{gdsm}$ with stale bread. Waste bread includes $60 \%$ of starch and $8.9 \%$ protein in dry base [23]. During growth, M. purpureus breaks down starch substrate into several metabolites, of which pigments are produced as secondary metabolites. In previous studies, the starch rich agricultural products were also studied as substrate for pigment production [24]. Lee et al., 1995 [25] used a tapioca starch for the Monascus pigment production and they reported that, $50 \mathrm{~g} / \mathrm{l}$ starch in the medium was ideal dose to observe the highest culture growth rate and pigment yield of Monascus.

\subsection{Purpureus Kinetics}

The applicability of stale bread and sour yoghurt as food wastes as substrates for Monascus pigment production were evaluated in Figure 3. 


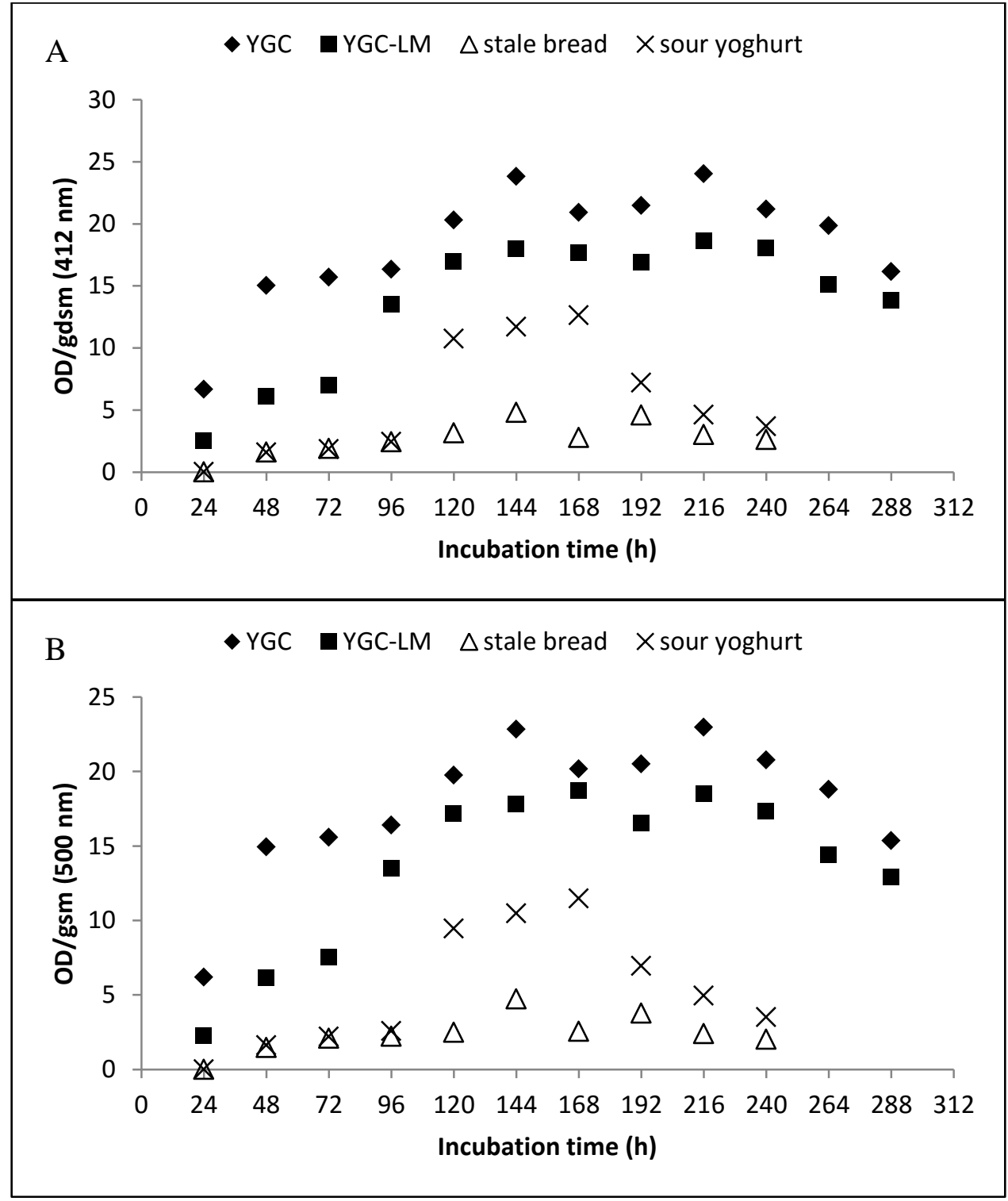

Figure 3. Growth and pigment yield of Monascus purpureus based on OD measurement at A: $412 \mathrm{~nm}$ and B:500 $\mathrm{nm}$ in various substrates

The comparisons of pigment production rates with defined medium were also performed. Spectral analysis indicated maximum absorbance at $412 \mathrm{~nm}$ and $500 \mathrm{~nm}$ were achieved when YGC was used. Since litmus milk favored proteolitic activity rather than pigment production, YGC-LM substrate yielded lower pigment yield than the YGC, as expected. Lower ethanol yield was also a good indication of this situation (Fig. 4). 


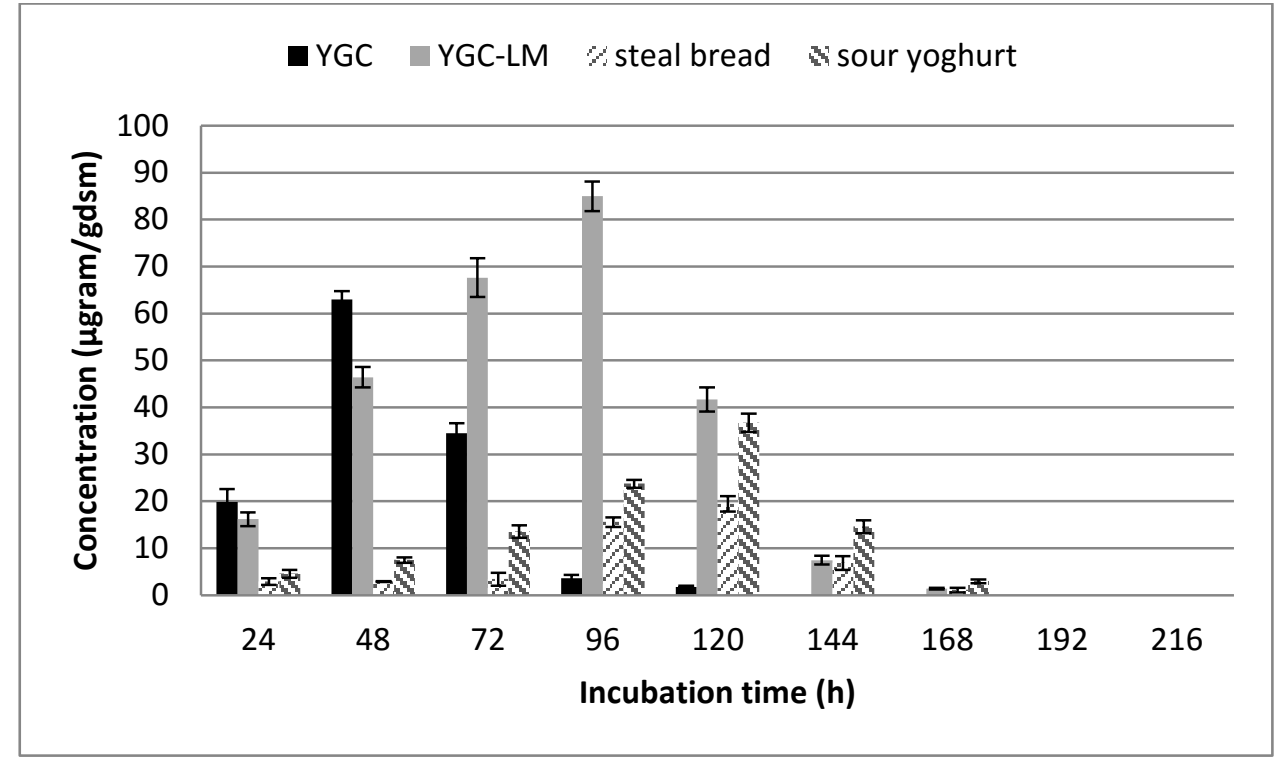

Figure 4. Ethanol production and consumption of M.purpureus grown on different substrates

In case of the food residues used as substrates, fermentation yielded red pigment concentration as $12.5 \mathrm{OD} / \mathrm{gdsm}$ for sour yoghurt and $4.8 \mathrm{OD} / \mathrm{gdsm}$ for stale bread, which were almost half and 1/6 of the highest pigment yield achieved with the defined media, respectively. In literature, for the other agro industrial wastes, highest pigment yield was achieved as; corn cob (25.4 OD/gdsm), coconut oil cake $(0.12 \mathrm{OD} / \mathrm{gdsm})$, tamarind seed powder $(1.15 \mathrm{OD} / \mathrm{gdsm})$, cassava flour $(1.46 \mathrm{OD} / \mathrm{gdsm})$, wheat bran $(3.52 \mathrm{OD} / \mathrm{gdsm})$, spent brewing grain (4.35 OD/gdsm), jackfruit seed powder (12.11 OD/gdsm) [25].

\subsection{Ethanol Formation/Consumption during the Growth Kinetic}

Fermentation studies showed that the final pigment yield correlated with the transient appearance of ethanol and its consumption. Many authors have reported on ethanol production in Monascus sp. both in submerged [26] and solid-substrate cultivation [27]. The levels of ethanol accumulated increased when the defined medium were used (Fig. 4). Since litmus milk supported to the metabolic activity, the biomass yield became higher, at the initial period of the fermentation (Fig. 2). Then, ethanol as a growth- associated metabolic product reached to the highest level as $84 \mu \mathrm{g} /$ gdsm at 4 th day of the fermentation (Fig. 4). Lee et al., 2001 [28] also indicated that, glucose concentration was very important, because increasing glucose concentration increased both biomass and pigment production up to the $30 \mathrm{~g} / \mathrm{L}$. However, although ethanol accumulation favored MPs production as a secondary metabolite, lower pigment formation was detected when LM used in the media formula (Fig. 3). This indicated that different substrates yielded varying pigment and metabolite production.

\subsection{HPLC Profile of monascus pigments}

HPLC chromatogram of Monascus pigments at $238 \mathrm{~nm}$ is shown in Fig. 5. 


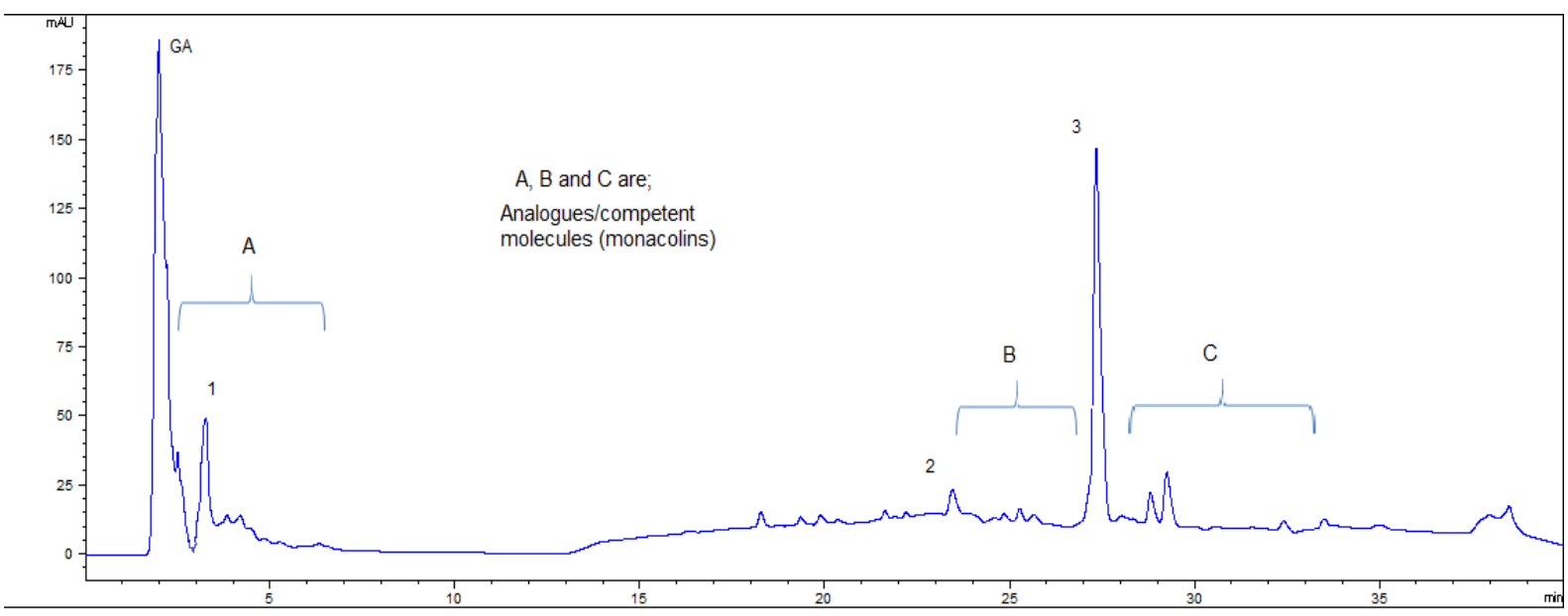

Figure 5. HPLC chromatogram of monascus metabolites; (detection at $238 \mathrm{~nm}$ ); 1: monacolin K; 2: hydroxy acid form of lovastatin; 3: Lactone form of lovastatin ad their possible analogues/compotent molecules in fermentation media (shown as A,B, and $\mathrm{C}$ regions). Chromatogram of Monascus purpureus fermentation sample, which was taken over the YGC agar at the end of the fermentation, contains gallic acid (24 $\mu \mathrm{g} \mathrm{GA} / \mathrm{mL})$ as an external standard

Due to the biosynthesis pathway of lovastatin and its analogues from acetate, these compounds were accumulated in the fermentation medium and resulted in complex environment. It has been reported that the presence of diene groups in lovastatin were responsible for this typical interference [19]. Some of the intermediates of lovastatin, such as monacolin J, X, L and M were also found to have maximum absorbance at $238 \mathrm{~nm}$ [29]. These compounds appear as probable interferences in the determination of MPs, such as lovastatin and monacolin (Regions A, B and C were signed on the chromatogram). However, relative comparative analysis was performed to evaluate the difference in metabolites of Monascus. A comparison was performed with the following formula;

$$
\text { GAEq. component }=\frac{G A \text { standart }(\mu \mathrm{g} / \mathrm{ml})}{\text { peak area of } \mathrm{GA}} \text { xpeak area of component }
$$

where GAEq. is the Gallic acid equivalent.

Table 1 tabulated the level of lovastatin and their analogues determined in the fermentation environment prepared with different substrates.

Table 1. Substrate effects on the monascus pigments; comparative analysis based on the gallic acid (GA); where samples were taken at the end of the fermentation

\begin{tabular}{|l|l|l|l|}
\hline Substrate & Monacolin K (GAEq.) & $\begin{array}{l}\text { Hydroxy acid form } \\
\text { Lovastatin (GAEq.) }\end{array}$ & $\begin{array}{l}\text { Lactone form Lovastatin } \\
\text { (GAEq) }\end{array}$ \\
\hline YGC & 8.78 & 2.44 & 25.44 \\
\hline YGC-LM & 4.17 & 5.56 & 21.65 \\
\hline Sour yoghurt & 2.11 & 3.17 & 16.41 \\
\hline Stale bread & 5.58 & 1.04 & 21.48 \\
\hline
\end{tabular}


Type, amount and yield of MPs differ due to the varying growth performances of M.purpureus on different substrates. Biosynthetic pathway also has a major role to determine the MPs composition. Furthermore, accumulation of certain components might eliminate to synthesize valuable bioactive molecules. As parallel to this observation, Xie et al., 2006 [30] reported the accumulation of monacolins especially, monacolin $\mathrm{J}$, inhibited lovastatin biosynthesis.

\subsection{Kinetic Model and Kinetic Parameters within Different Substrates}

The non-linear fitting of kinetic equations was conducted with the experimental data and the kinetic parameters were determined using Matlab software (Fig. 6).

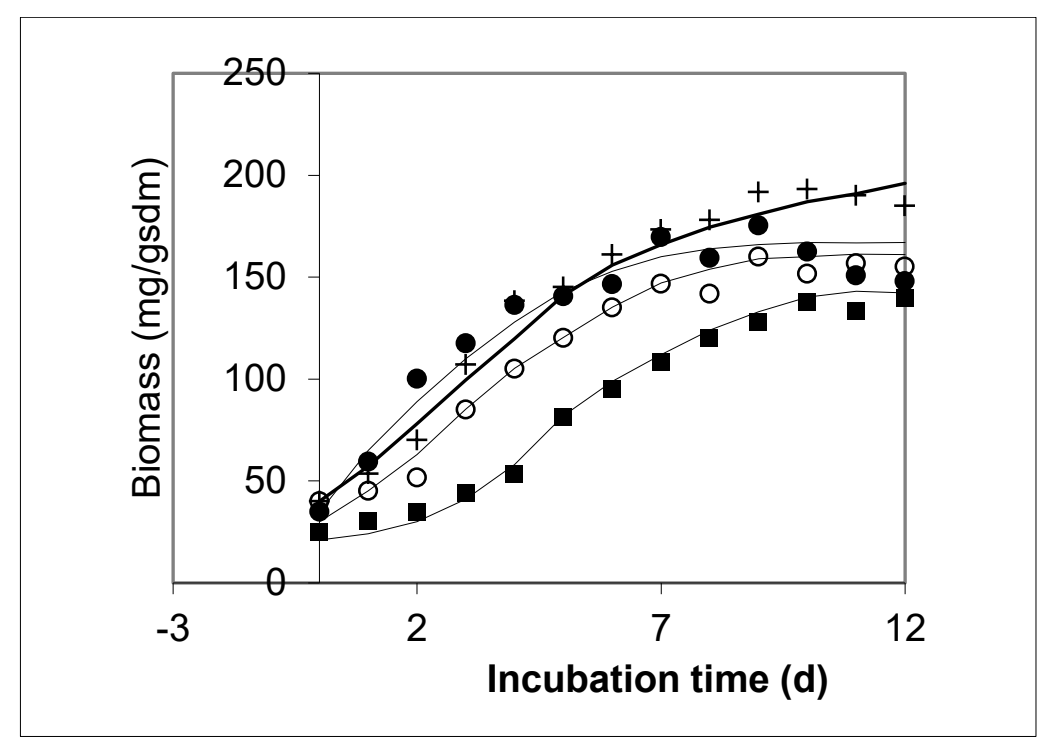

Figure 6. Model (-) and experimental data of biomass for different substrates; YGC (+); YGC-LM (•); sour yoghurt (o); stale bread ( $\square$ ).

The maximum specific growth rate, $\mu_{\max }$ and $\mathrm{K}_{\mathrm{s}}$ values were tabulated in Table 2 . The constant $\mathrm{K}_{\mathrm{s}}$ is the concentration of the rate-limiting substance when the specific rate of growth is equal to one-half of its maximum. It is also known as the Monod or saturation constant and shows the affinity of the organism for the growth-limiting substrate [20].

Table 2. Model parameters and correlation coefficients for different substrates used

\begin{tabular}{|c|c|c|c|}
\hline Substrate & $\mu_{\max }$ & $\mathrm{K}_{\mathrm{s}}$ & $\mathrm{R}^{2}$ \\
\hline YGC & 0.412 & 0.78 & 0.979 \\
\hline YGC-LM & 0.432 & 0.81 & 0.950 \\
\hline Sour yoghurt & 0.406 & 0.64 & 0.986 \\
\hline Stale bread & 0.387 & 0.67 & 0.996 \\
\hline
\end{tabular}

Due to the different nutrient properties of substrates, they provided different microenvironments for the M.purpureus growth, metabolite and MPs production. Hence, the kinetic parameters were apparently different between all fermentation systems. As shown in the Table 1, the maximum specific growth rate $\left(\mu_{\max }\right)$ was achieved highest when the YGCLM used as a substrate. The metabolic function and ethanol formation also supported this high value. However, $\mu_{\max }$ values of sour yoghurt and stale bread also very close to the 
defined medium's values. This indicated that, food residues could effectively be used as substrates for the $M$. purpureus growth.

\section{CONCLUSION}

This research attempts to identify main stages of the M.purpureous adaptation, growth performance and link them to changes in Monascus metabolites during the fermentation period. Non-growth associated product formation was established and product formation was achieved after ethanol accumulation in the fermentation environment. According to the promising results achieved, Monascus pigment production by fermentation using complex media such as bread and yoghurt residues or wastes is feasible, economic and safe process. This process has the facility of converting no-value food wastes to the Monascus pigments and metabolites, which serve functional properties for food industry. Resultant Monascus pigments have great potential of replacing synthetic food colorants by these natural ones.

\section{REFERENCES}

[1] Buka I, Osornia-Vargas A, Clark B. Food Additives, Essential Nutrients and Neurodevelopmental Behavioural Disorders in Children: A Brief Review, Paediatrics and Child Health, No. 16, 2011, pp.e54-e56.

[2] Eigenmann P A, Haenggeli C A. Food colourings, preservatives, and hyperactivity, Lancet, No.370, 2007, 1524-1525.

[3] Ceyhan BM, Gültekin F, Doğuç DK, Kulaç E. Effects of Maternally Exposed Coloring Food Additives in Receptor Expressions Related to Learning and Memory Rats, Food and Chemical Toxicology, No. 56, 2013, pp.145-148.

[4] Axon A, May FEB, Gaughan LE, Williams FM, Blain PG, Wright MC. Tartrazine and Sunset Yellow are Xenoestrogens in a New Screening Assay to Identify Modulators of Human Oestrogen Receptor Transcriptional Activity, Toxicology, No. 298, 2012, pp.4051.

[5] Amin KA, Hameid HA, Elsttar AHA. Effect of Food Azo Dyes Tartrazine and Carmoisine on Biochemical Parameters Related to Renal, Hepatic Function and Oxidative Stress Biomarkers in Young Male Rats, Food and Chemical Toxicology, No. 48, 2010, pp.29942999.

[6] Kohno Y, Kitamura S, Yamada T, Sugihara K, Ohta S. Production of Superoxide Radical in Reductive Metabolism of a Synthetic Food-Coloring Agent, Indigocarmine, and Related Compounds, Life Sciences, No. 77, 2005, pp.601-614.

[7] Babitha S, Soccol CR, Pande A. Jackfruit Seed-A Novel Substrate for the Production of Monascus Pigments through Solid State Fermentation, Food Technology and Biotechnology, No. 44, 2006, pp.465-471.

[8] Lin YL, Wang TH, Lee MH, Su NW. Biologically Active Components and Nutraceuticals in the Monascus- Fermented Rice: A Review, Applied Microbiology and Biotechnology, No. 77, 2008, pp.965-973.

[9] Lee CL, Kung YH, Wu CL, Hsu YW, Pan TM. Monascin and ankaflavin Act as a Novel Hypolipidemic and High-Density Lipoprotein Cholesterol-Raising Agents in Red Mold Dioscorea, Journal of Agricultural and Food Chemistry, No. 58, 2010, pp.9013-9019.

[10] Patakova P. Monascus Secondary Metabolites: Production and Biological Activity, Journal of Industrial Microbiology and Biotechnology, No. 40, 2013, pp.169-181.

[11] Hsu LC, Hsu YW, Liang YH, Liaw CC, Kuo YH, Pan TM. Induction of Apoptosis in Human Breast Adenocarcinoma Cells MCF-7 by Monapurpyridine A, a New Azaphilone 
Derivative from Monascus Purpureus NTU 568, Molecules, No. 17, 2012, pp.664-673.

[12] Zheng Y, Xin Y, Shi X, Guo Y. Cytotoxicity of Monascus Pigments and their Derivatives to Human Cancer Cells, Journal of Agricultural and Food Chemistry, No. 58, 2010, pp.9523-9528.

[13] Akihisa T, Tokuda H, Yasukawa K, Ukiya M, Kiyota A, Sakamoto N, Suzuki T, Tanabe N, Nishino H. Azaphilones, Furanoisophthalides, and Amino Acids from the Extracts of Monascus Pilosus-Fermented Rice (Red Mold Rice) and their Chemopreventive Effects, Journal of Agricultural and Food Chemistry, No. 53, 2005, pp.562-565.

[14] Pattanagul P, Pinthong R, Phianmongkho A, Leksawasdi N. Review of Angkak Production (Monascus purpureus), Chiang Mai Journal of Science, No. 34, 2007, pp.319-328.

[15] Mu H, Huang L, Ding X, Zhao S. Influence of Different Substrates on the Production of Pigments and Citrinin by Monascus FJ46, $2^{\text {nd }}$ International Conference on Applied Biotechnology, 2014, pp.257-264.

[16]Shi YC, Pan TM. Beneficial Effects of Monascus Purpureus NTU 568-Fermented Products: A Review, Applied Microbiology and Biotechnology, No. 90, 2011, pp.12071217.

[17] Zhang BB, Lu LP, Xu GR. Why Solid-State Fermentation is More Advantageous Over Submerged Fermentation for Converting High Concentration of Glycerol into Monacolin K by Monascus Purpureus 9901: A Mechanistic Study, Journal of Biotechnology, No. 206, 2015, pp.60-65.

[18] Skoog DA, West DM, Holler FJ, Crouch SR. Fundamentals of Analytical Chemistry, New York: Saunders College Publishing, 2003, pp.575.

[19] Seenivasan A, Gummadi SN, Panda T, Thedore T. Quantification of Lovastatin Produced by Monascus Purpureus, The Open Biotechnology Journal, No. 9, 2015, pp.6-13.

[20] Altıok D, Tokatlı F, Harsa S. Kinetic Modelling of Lactic Acid Production from Whey by Lactobacillus Casei (NRRL B-441), Journal of Chemical Technology and Biotechnology, No. 81, 2006, pp.1190- 1197.

[21] Rasheva T, Hallet JN, Kujumdzieva A. Taxonomic Investigation of Monascus Purpureus 94-25 Strain, Journal of Culture Collection, No. 2, 1998, pp.51-59.

[22] Tseng YY, Chen MT, Lin CF. Growth, Pigment Production and Protease Activity of Monascus Purpureus as Affected by Salt, Sodium Nitrite, Polyphosphate and Various Sugars, Journal of Applied Microbiology, No. 88, 2000, pp.31-37.

[23] Leung CCJ, Cheung ASY, Zhang AYZ, Lam KF, Lin CSK. Utilisation of Waste Bread for Fermentative Succinic Acid Production, Biochemical Engineering Journal, No. 65, 2012, pp.10-15.

[24] Babitha S, Microbial Pigments, in Biotechnology for Agro-Industrial Residues Utilization, (Ed) Singh Nee' Nigam, A. Pandey, The Netherlands: Springer, 2009, pp.147-162.

[25] Lee YK, Chen DC, Chauvatcharin S, Seki T, Yoshida T. Production of Monascus Pigments by a Solid-Liquid State Culture Methods, Journal of Fermentation and Bioengineering, No. 79, 1995, pp.516-518.

[26] Chen MH, Jhons MR. Effect of Carbon Source on Ethanol and Pigment Production by Monascus Purpureus, Enzyme and Microbial Technology, No. 6, 1994, pp.584-590.

[27] Hamdi M, Blanc PJ, Goma G. Effect of Aeration Conditions on the Production of Red Pigments by Monascus Purpureus Growth on Prickly Pear Juice, Process Biochemistry, No. 31, 1996, pp.543-547.

[28] Lee BK, Park NH, Piao HY, Chung WJ. Production of Red Pigments by Monascus Purpureus in Submerged Culture, Biotechnology and Bioprocess Engineering, No. 6, 
2001, pp.341-346.

[29] Li YG, Zhang F, Wang ZT, Hu ZB. Identification and Chemical Profiling of Monacolins in Red Rice Using High Performance Liquid Chromatography with Photodiode Array Detector and Mass Spectrometry, Journal of Pharmceuticals and Biomedical Analysis, No. 35, 2004, pp.1101-1112.

[30] Xie X, Watanable K, Wojcicki WA, Wang CC, Tang Y. Biosynthesis of Lovastatin Analogs with a Broadly Specific Acetyltransferase, Chemistry and Biology, No. 13, 2006, pp.1161-1169.

\section{ÖZGEÇMIȘ/CV}

\section{Evren ALTIOK; Assist.Prof (Yrd.Doç.Dr.)}

He got his bachelors' degree in the Food Engineering Department at Ege University, İzmir/Turkey in 1999, his master degree in the Biotechnology and Bioengineering Graduate program at Izmir Institute of Technology, Izmir/Turkey in 2003, PhD degree in the Chemical Engineering Department Izmir Institute of Technology, Izmir/Turkey in 2010. Between 2011 and 2015, he was an academic member of the Food Engineering Department at Istanbul Aydin University. He has assigned to Giresun University as an Assistant Professor and he is still an academic member of the Genetic and Bioengineering Department at Giresun University. His major areas of interests are: Natural compounds and their bioactivities, adsorption and separation processes, natural polymers, Food engineering Unit Operations; i.e. drying processes, evaporation, encapsulation.

Lisans derecesini 1999'da Ege Üniversitesi Glda Mühendisliği Bölümü'nden, Yüksek Lisans derecesini 2003'de İzmir Yüksek Teknoloji Enstitüsü Biyoteknoloji Anabilim dalından, Doktora derecesini 2010 yllında İzmir Yüksek Teknoloji Enstitüsü Kimya Mühendisliği Bölümü'nden aldl. 2011-2015 yllarl arasinda İstanbul Aydın Üniversitesi Gıda Mühendisliği Bölümü̈nde öğretim üyesi olarak görev aldl. 2015 yllında Giresun Üniversitesi Genetik ve Biyomühendislik Bölümü'ne Yrd. Doç. Dr. olarak atandı ve hala bölümde ögrretim üyesi olarak görev yapmaktadır. Temel çalışma alanları: Doğal Bileşenler ve bu bileşenlerin biyoaktiviteleri, Adsorpsiyon ve Ayırım Isşlemleri, Doğal Polimerler, Gıda Temel Işslemleri (kurutma iş̧lemleri, evaporasyon, enkapsülasyon vb.) üzerinedir.

Duygu ALTIOK; Assist.Prof (Yrd.Doç.Dr.)

She got his bachelors' degree in the Food Engineering Department at Middle East Technical University in 2000, her master degree in the Food Engineering Department at Izmir Institute of Technology in 2004, PhD degree in the Chemical Engineering Department at Izmir Institute of Technology in 2011. Between 2011-2015, she was an academic member of the Food Engineering Department at Istanbul Aydin University. She has assigned to Giresun University as an Assistant Professor in 2015 and she is still an academic member of the Food Engineering Department at Giresun University. Her major areas of interests are: Fermentation, kinetic modelling, spray drying and microencapsulation.

Lisans derecesini 2000'de Orta Doğu Teknik Üniversitesi Glda Mühendisliği Bölümü'nden, Yüksek Lisans derecesini 2004'te İzmir Yüksek Teknoloji Enstitüsü Glda Mühendisliği Bölümü’nden, Doktora derecesini 2011'de İzmir Yüksek Teknoloji Enstitüsü Kimya Mühendisliği Bölümü'nden aldl. 2011-2015 yılları arasında İstanbul Aydın Üniversitesi Gida Mühendisliği Bölümü'nde ögretim üyesi olarak görev aldl. 2015 yllında Giresun Üniversitesi Gıda Mühendisliği Bölümü'ne Yrd. Doç. Dr. olarak atandı ve hala bölümde öğretim üyesi olarak görev yapmaktadır. Temel çalışma alanlart: Fermentasyon, kinetik modelleme, püskürtmeli kurutma ve mikroenkapsülasyon üzerinedir.

\section{Gülşen NAS; Research Assist. (Araştırma Görevlisi)}

She got her bachelors' degree in the Food Engineering Department at İstanbul Aydın University, İstanbul/Turkey in 2014. She started her master degree education at the same university and department. She has also assigned as TA in the Food Engineering Department at Istanbul Aydin University.

Lisans derecesini 2014'de İstanbul Aydın Üniversitesi Gıda Mühendisliği Bölümü’nden Bölüm birincisi derecesi ile aldı. Eş zamanlı başladı̆̆g yüksek lisans eğitimine yine aynı Üniversite ve Bölümde devam etmekte ve aynı zamanda İstanbul Aydin Üniversitesi’nde Araştırma Görevlisi olarak görev almaktadır. 